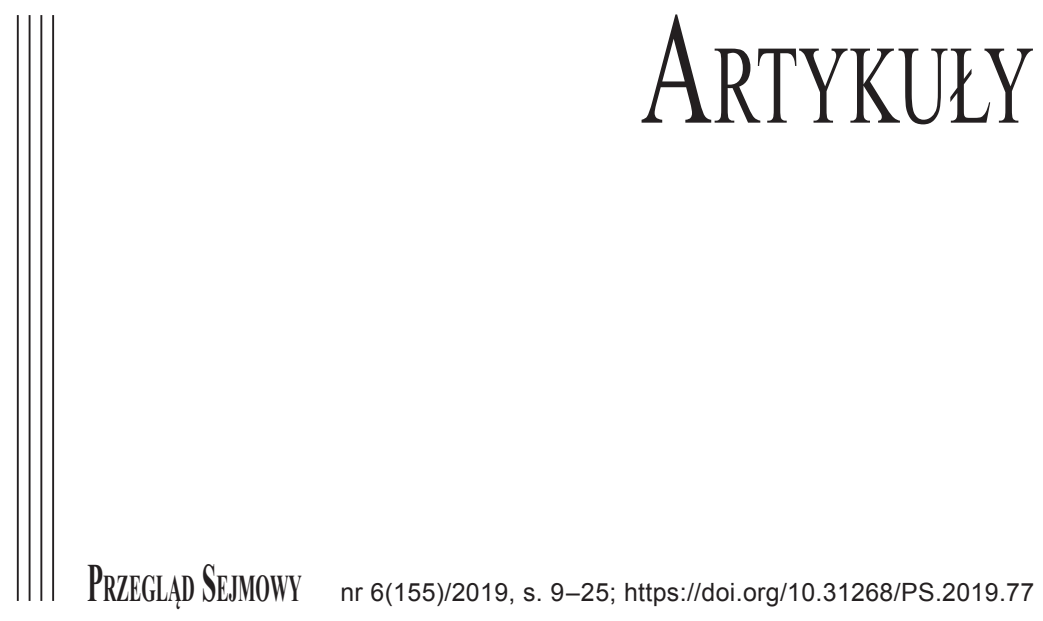

ARKADIUSZ ADAMCZYK*

\title{
WERCHOWNA RADA UKRAINY WOBEC WYBUCHU KONFLIKTU NA MORZU AZOWSKIM (LISTOPAD 2018 R.)
}

Konflikt Federacji Rosyjskiej z Ukrainą na Morzu Azowskim (zwany też konfliktem kerczeńskim) jest drugim — po zagarnięciu przez Rosję półwyspu krymskiego — polem rywalizacji, które de facto i de iuris nie zostało doprowadzone do jakiegokolwiek finału. Stanowi przykład działań politycznych generowanych przez Rosję, w której Federacja — w zależności od zapotrzebowania - sprawuje pełną kontrolę nad przebiegiem działań wojennych i posunięć dyplomatycznych, eskalując napięcie bądź też wprowadzając spór w stan zamrożenia. W tych ostatnich kategoriach należy postrzegać incydent na Morzu Azowskim 25 listopada 2018 r. Forsując tę tezę, trzeba zwrócić uwagę na wybór terminu incydentu. Nastąpił on bowiem na kilka miesięcy przed wyborami na Ukrainie i jak się wydaje, miał stanowić jeden z elementów próby wpływu Rosji na zagwarantowanie elekcji ugrupowaniom jej przyjaznym. W sytuacji kryzysu swoje stanowisko musiała zająć Werchowna Rada Ukrainy. Celem artykułu jest wykazanie, że deputowani nie tylko wykorzystali wszelkie konstytucyjne uprawnienia do wsparcia działań władzy wykonawczej (prezydenta i rządu), ale w sposób znaczący wyszli poza swe prerogatywy. Stanowi również przyczynek do badań nad zachowaniami systemów legislacyjnych w sytuacjach kryzysowych.

Słowa kluczowe: Werchowna Rada Ukrainy, kryzys polityczny, Ukraina, Federacja Rosyjska, Unia Europejska, kryzys kerczeński

\section{THE VERKHOVNA RADA OF UKRAINE AGAINST THE OUTBREAK OF THE AZOV SEA CONFLICT (NOVEMBER 2018)}

The conflict between the Russian Federation and Ukraine on the Azov Sea (also called the Kerch Strait conflict) is the second field of rivalry - after Russia had seized Crimea by force - which has not been finalized either de facto or de iuris. It is an example of a political action generated by Russia, where the Federation - depending on current demands - exercises full control over the course of warfare and diplomatic actions by either escalating the tension or freezing the conflict. The Azov Sea incident of 25 November 2018 shall be regarded in those categories. Proposing this thesis, the date of the incident must be taken into account. It took place a few months before elections in Ukraine and, as it seems, it was to be one of the elements 
of Russia's attempts at influencing the election and ensuring the victory of Russia-oriented political parties. In the crisis situation, the Verkhovna Rada of Ukraine had to take a position. The aim of the article is to demonstrate that the deputies not only used all constitutional entitlements to support actions of the executive (President and government), but also significantly exceeded their prerogatives. Moreover, the article is a contribution to the research of the legislative systems' conduct in crisis situations.

Key words: Verkhovna Rada of Ukraine, political crisis, Ukraine, Russian Federation, European Union, Kerch Strait Conflict

* Dr hab. Arkadiusz Adamczyk, Uniwersytet Jana Kochanowskiego w Kielcach, adark@interia.pl, https://orcid.org/0000-0003-0561-0230

\section{PIERWSZE REAKCJE WERCHOWNEJ RADY UKRAINY NA WYDARZENIA NA MORZU AZOWSKIM}

\ompetencje parlamentu Ukrainy jako organu inicjującego rozwiązania w prze1 strzeni międzynarodowej pozostawały mocno ograniczone. Deputowani Werchownej Rady, oprócz aktywności medialnej i obecności w przestrzeni publicznej, byli zmuszeni czekać na decyzje prezydenta. Nie oczekiwali zresztą nadmiernie długo. Jeszcze tego samego dnia, w którym siły FR zaatakowały jednostki ukraińskie, prezydent Petro Poroszenko zapowiedział, że zwróci się do izby ustawodawczej z wnioskiem o wprowadzenie stanu wojennego na terytorium Ukrainy ${ }^{1}$. Jak zresztą stwierdził: „Wprowadzenie stanu wojennego nie oznacza, że Ukraina będzie prowadziła działania ofensywne. Ukraina będzie prowadziła wyłącznie działania na rzecz obrony swojego terytorium i bezpieczeństwa swoich obywateli. [...] Stan wojenny nie oznacza, że rezygnujemy z polityczno-demokratycznej drogi wyzwolenia ukraińskich terytoriów"2. Zapowiedź głowy państwa spotkała się z natychmiastową reakcją przewodniczącego Werchownej Rady Andrija Parubija, który w trybie pilnym zwołał posiedzenie ukraińskiego parlamentu ${ }^{3}$. Obrady, do których doszło 26 października w godzinach popołudniowych,

${ }^{1}$ Kancelaria Prezydenta Ukrainy, dekret Prezydenta Ukrainy nr 390/2018 (26 listopada 2018 r.).

2 A. Ferris-Rotman, Ukraine to impose martial law as standoff with Russia in Black Sea intensifies, „Washington Post”, 27 XI 2018,< https://www.washingtonpost.com>, dostęp 6 IV 2019.

${ }^{3}$ Przewodniczący Werchownej Rady w godzinach porannych 26 listopada 2018 r. rozesłał do deputowanych informację: „Dzisiaj na statku marynarki wojennej przeprowadzono atak morski na rosyjskie wojsko. Takie działania rosyjskiego agresora — naruszenie norm Karty Narodów Zjednoczonych, Konwencji Narodów Zjednoczonych o prawie morza. Cały świat widział dowody rosyjskiej agresji militarnej, z którą nikt nie może się spierać. W końcu cały świat widział wideo z rosyjskich okrętów wojennych atakujących Ukraińców. W piątym roku rosyjska agresja na Ukrainę trwa. Krym i część regionów Doniecka i Ługańska są zajęte. Prawie codziennie stanowiska naszych wojskowych są wyrzucane przez rosyjskich terrorystów w Donbasie. Oczywiście front rosyjskiej agresji rozszerzył się i teraz dociera do mórz czarnych i azowskich. Zgodnie z decyzją Rady Bezpieczeństwa Narodowego i Obrony Ukrainy oraz przemówieniem Prezydenta Ukrainy, w poniedziałek 26 listopada 2018 r., O godzinie 16:00 zwołam nadzwyczajne posiedzenie Rady Najwyższej Ukrainy”. Werchowna Rady Ukrainy, sekretariat przewodniczącego Werchownej Rady, oświadczenie A. Parubija, przewodniczącego Werchownej Rady, w sprawie zwołania nadzwyczajnej sesji Werchownej Rady z 26 listopada 2018 r. [tłum. własne, A.A.]. 
odbywały się już pod presją zarządzeń prezydenta i głównodowodzącego Sił Zbrojnych Ukrainy, którzy zdecydowali o postawieniu armii w stan pełnej gotowości bojowej. Niewątpliwe politycznym wsparciem dla deputowanych były oświadczenia przedstawicieli Polski, Stanów Zjednoczonych, Turcji, Francji i Wielkiej Brytanii a także Unii Europejskiej i NATO, wyrażające zaniepokojenie z powodu agresji w Cieśninie Kerczeńskiej.

Samo rozpoczęcie i dalszy przebieg posiedzenia były świadectwem $-\mathrm{z}$ jednej strony - świadomości wagi zaistniałego problemu, z drugiej — determinacji deputowanych. Wkrótce po otwarciu przez przewodniczącego Werchownej Rady nadzwyczajnej sesji przedstawiciele Partii Radykalnej pod przewodnictwem Olega Ljaszko otoczyli prezydium, żądając obecności i natychmiastowej reakcji prezydenta Ukrainy. Dopiero po częściowym złagodzeniu nastrojów i zapowiedzi przybycia na posiedzenie Werchownej Rady premiera Wołodymyra Hrojsmana wraz z ministrami A. Parubij mógł wygłosić w imieniu deputowanych pierwsze polityczne oświadczenie. Przedstawił w nim incydent $\mathrm{z}$ dnia poprzedniego jako kontynuację agresywnych działań przeciwko Ukrainie, zapoczątkowanych napaścią reżimu Putina na Krym i okupacją terytoriów przyległych Doniecka i Ługańska. Jak stwierdził, ,[...] wczoraj, po raz pierwszy, Federacja Rosyjska, która zgodnie z memorandum budapeszteńskim była jednym z gwarantów bezpieczeństwa Ukrainy, otwarcie użyła siły zbrojnej przeciwko Ukrainie". Podobne stwierdzenia wybrzmiały w wystąpieniu sekretarza Rady Bezpieczeństwa Narodowego i Obrony [dalej: RBNiO] Ołeksandra Turczinowa. Oprócz zaznajomienia deputowanych z przebiegiem zajść w Cieśninie Kerczeńskiej sekretarz RBNiO poinformował, że w związku z groźbą dalszej inwazji sił zbrojnych Federacji Rosyjskiej oraz postępującego zagrożenia suwerenności państwa i niepodległości Ukrainy RBNiO rekomendowała prezydentowi Ukrainy wprowadzenie dekretu o wprowadzeniu stanu wojennego na Ukrainie. Choć Turczinow stwierdził wobec przedstawicielstwa narodowego, że wprowadzenie stanu wojennego wiązało się nieodmiennie z ograniczeniem praw obywateli i koniecznością ponoszenia ofiar „zgodnie z konstytucją i ustawodawstwem Ukrainy", to jednak prezydent nie planował literalnego zastosowania tego przepisu. Celem wprowadzenia stanu wojennego miało być jedynie uzyskanie instrumentu pozwalającego głowie państwa na reakcję w przypadku dalszego pogorszenia sytuacji międzynarodowej i położenia militarnego. Jednocześnie zaapelował do deputowanych o poparcie projektu ustawy o zatwierdzeniu dekretu prezydenckiego w sprawie wprowadzenia statusu wojskowego na Ukrainie. Odnosząc się do wewnętrznych skutków agresji FR, Turczinow jednoznacznie przeciął spekulacje odnoszące się do pogłoski o chęci przeniesienia wyborów prezydenckich poza termin ustalony przepisami konstytucji Ukrainy. Wypowiedź sekretarza RBNiO została uzupełniona przez ministra spraw zagranicznych Pawlo Klimkina. Szef ukraińskiej dyplomacji ograniczył się do przekazania informacji dotyczących kwalifikacji rosyjskiego ataku z punktu widzenia prawa międzynarodowego (jako pierwszy użył twierdzenia, że ,[...] działania Federacji Rosyjskiej na okrętach Sił Morskich Ukrainy są bezpośrednim otwartym i nieskrywanym aktem agresji na Ukrainę w rozumieniu art. 2 Karty Narodów Zjednoczonych"), podkreślił pełną odpowiedzialność FR za destabilizację ładu na Morzu Azowskim oraz 
lakonicznie poinformował deputowanych o podjęciu konsultacji z zagranicznymi partnerami. Szerzej skupił się natomiast na kwestii pozbawionych wolności marynarzach ukraińskich, których — jak stwierdził — ,zgodnie z międzynarodowym prawem humanitarnym [...] należy uznać za jeńców wojennych”. Klimkin przed forum parlamentarnym określił bieżące cele polityczne, jakie w związku z napaścią zamierzało zrealizować państwo ukraińskie. Za priorytet zostało uznane uwolnienie marynarzy i odzyskanie zagrabionego ukraińskiego mienia. W dalszej kolejności państwo ukraińskie miało dążyć do ukarania Rosji i objęcia FR nowymi sankcjami polityczno-ekonomicznymi. Klimkin zapowiedział też starania o zapewnienie efektywnego bezpieczeństwa na Morzu Czarnym „W obliczu świadomej eskalacji sytuacji po stronie Rosji”. W dalszej części debaty wziął udział szef Sztabu Generalnego gen. Wiktor Mużenko, który jednak poza informacjami dotyczącymi szczegółów incydentu nie wniósł niczego nowego do toczonej debaty politycznej.

Przemówienia Turczinowa, Klimkina i Mużenki stanowiły zaledwie wstęp do oczekiwanych przez deputowanych wystąpień najwyższych przedstawicieli władzy wykonawczej Ukrainy. Zgodnie z przewidywaniami zarówno premier, jak i prezydent przedstawili parlamentarzystom Werchownej Rady informacje o aktualnych posunięciach politycznych i prognozach na najbliższą przyszłość. Nie sposób nie odnieść wrażenia, że były to przemówienia nie tylko ściśle ze sobą korelujące, lecz również stanowiące świadectwo podziału zadań, jaki w sposób naturalny zaistniał w okresie kryzysu. Wołodymir Hrojsman położył szczególny nacisk na zagadnienia oceny sytuacji wewnętrznej i zewnętrznej oraz stabilności kraju, potrzebę zachowania porządku społecznego oraz utrzymania ładu gospodarczego i zdolności nieskrępowanej zagranicznej wymiany handlowej. Zwrócił też uwagę na odpowiedzialność polityków za zdrowie i życie ukraińskiej armii, co stanowiło zakamuflowaną, aczkolwiek czytelną deklarację determinacji nieeskalowania konfliktu z Rosją. Prezydent z kolei odniósł się niemal wyłącznie do potrzeby wprowadzenia wewnętrznych rozwiązań prawnych w postaci ,wprowadzenie stanu wojennego wyłącznie na obszarach położonych wzdłuż granicy rosyjskiej, naddniestrzańskiego odcinka granicy ukraińsko-mołdawskiej i wzdłuż wybrzeża Morza Czarnego i Azowskiego".

Odpowiadając na ówczesne zapotrzebowanie, Werchowna Rada podjęła — zgodnie z pkt 31 art. 85 konstytucji Ukrainy oraz art. 5 ustawy o reżimie prawnym stanu wojennego - uchwałę o wprowadzeniu na okres 30 dni stanu wojennego $0^{4}$, z ewentualnym prawem przedłużenia na kolejne okresy aż do czasu przeprowadzenia wolnych wyborów ${ }^{5}$. Stan wojenny miał jedynie obowiązywać na obszarach województw winnickiego, ługańskiego, mikołajowskiego, odeskiego, sumskiego, czernihowskiego, charkowskiego, donieckiego, zaporoskiego, chersońskiego oraz wód terytorialnych Ukrainy. Na tych obszarach Werchowna Rada przekazywała prezydentowi pełne uprawniania do decydowania o ewentualnym użyciu sił zbrojnych, przeprowadzenia nadzwyczajnego poboru

\footnotetext{
${ }^{4}$ Werchowna Rady Ukrainy. Zbiór projektów ustaw, druk nr 9338: projekty ustawy zatwierdzającej dekret prezydenta o wprowadzeniu stanu wojennego na Ukrainie.

5 Dziennik Werchownej Rady Ukrainy z 2018 r., nr 48, s. 397.
} 
i reagowania „zgodnie z potrzebami i adekwatnie do zagrożenia dla bezpieczeństwa Ukrainy". Uchwała przyjęta została większością głosów: 276 deputowanych głosowało za jej uchwaleniem, 30 było przeciw, jeden z parlamentarzystów wstrzymał się, zaś 23 nie wzięło udziału w głosowaniu. Na tym samym posiedzeniu Werchowna Rada przyjęła poprawki do ustawy o bezpieczeństwie narodowym Ukrainy ${ }^{6}$ oraz o ochronie informacji ${ }^{7}$ W obu przypadkach celem inicjujących te zmiany deputowanych Igora Kotwickiego i Andrija Tertiuka było „uszczelnienie systemu i zapobieganie, wczesne wykrywanie, wypowiedzenie lub zneutralizowanie rzeczywistych i potencjalnych zagrożeń dla bezpieczeństwa informacji Ukrainy”. Ponadto podniesienie „wypływu informacji” do rangi przestępstwa przeciwko narodowi i konstytucji miało na celu stworzenie instrumentu penalizacji zachowań godzących w interes państwa ukraińskiego.

Najważniejszym aktem politycznym, na jaki Werchowna Rada zdobyła się w kilka godzin po agresji FR na terytorium państwa ukraińskiego, była rezolucja uchwalona „W związku z kolejnym aktem agresji przeciwko Federacji Rosyjskiej”. Wystąpienie powstałe z inicjatywy deputowanej Iriny Geraszczenko skierowane zostało do Zgromadzenia Ogólnego Organizacji Narodów Zjednoczonych, Parlamentu Europejskiego, Zgromadzenia Parlamentarnego Rady Europy, Zgromadzenia Parlamentarnego Paktu Północnoatlantyckiego, Zgromadzenia Parlamentarnego Organizacji Bezpieczeństwa i Współpracy w Europie, Zgromadzenia Parlamentarnego zrzeszającego Gruzję, Ukrainę, Azerbejdżan i Mołdawię Organizacji na rzecz Demokracji i Rozwoju, parlamentów narodowych krajów świata ${ }^{8}$. Parlament ukraiński winą za zaistniałą sytuację jednoznacznie obarczył siły zbrojne FR, które — jak napisano w dokumencie — ,dokonały zbrojnego ataku na wojskowe jednostki morskie Sił Morskich Ukrainy, które przeprowadziły planowane przejście morskie z portu Odessa do portu Mariupol, zgodnie z postanowieniami obowiązujących wielostronnych i dwustronnych umów międzynarodowych i zasad nawigacji”. Deputowani podkreślili, że wydarzenia na Morzu Azowskim były kontynuacją agresywnych działań zapoczątkowanych 20 lutego $2014 \mathrm{r}$. agresją na Półwysep Krymski i sprzeczną z prawem międzynarodowym okupacją Autonomicznej Republiki Krymu, miasta Sewastopol oraz części terytoriów wchodzących w skład obwodów donieckiego i ługańskiego. Obwinili Rosjan o naruszenie art. 2 i 21 Konwencji Narodów Zjednoczonych o prawie morza z 1982 r., rezolucji Zgromadzenia Ogólnego ONZ nr 3314 z 14 grudnia 1974 r., a przede wszystkim o sprzeniewierzeniu się art. 2 Karty Narodów Zjednoczonych. Deputowani Werchownej Rady wyrażali zdecydowany protest $\mathrm{w}$ związku $\mathrm{z}$ agresją FR i przejęciem przez rosyjskie siły zbrojne ukraińskich łodzi wojskowych Berdiańsk, Nikopol i holownika Yana Kapua, a także w związku z ostrzelaniem, poranieniem i pozbawieniem wolności ukraińskich marynarzy. Rezolucja ukraińskiego parlamentu określała „reżim Kremla”, mianem podmiotu ponoszącego „pełną odpowiedzialność za eskalację napięć na Morzu Azowskim i Czarnym oraz w regionie Cieśniny Kerczeńskiej”, źródłem niestabilności regionu, a także

${ }^{6}$ Dziennik Werchownej Rady Ukrainy z 2018 r., nr 31, s. 24.

7 Dziennik Werchownej Rady Ukrainy z 1992 r., nr 48, s. 650.

${ }^{8}$ Dziennik Werchownej Rady Ukrainy z 2018 r., nr 48, s. 398. 
tworu kreującego działania przekreślające dążenia do pokojowego uregulowania konfliktu ukraińsko-rosyjskiego. W rezolucji wskazywano, że FR wyraźnie lekceważyła stanowisko społeczności międzynarodowej, czego wyrazem było m.in. przeprowadzenie „wyborów” na tymczasowo okupowanych terytoriach wokół Doniecka i Ługańska. Zdaniem deputowanych FR odpowiadała nie tylko za bezprawne działania, lecz również za ich konsekwencje, a przede wszystkim za niweczenie dążeń do zakończenia procesu pokojowego. Werchowna Rada sformułowała postulat udzielenia szybkiej i efektywnej pomocy medycznej rannym oraz zapewnienia im, jak również pozostałym marynarzom „,natychmiastowego i bezpiecznego powrotu na Ukrainę”, odnosząc się do kwestii wzięcia w niewolę żołnierzy pływających pod ukraińską banderą. To samo żądanie sformułowano wobec nielegalnie zagarniętego sprzętu wojskowego. Parlamentarzyści ukraińscy wezwali społeczność międzynarodową do uruchomienia politycznych instrumentów służących nie tylko powstrzymaniu rosyjskiej agresji na morzu i lądzie, lecz również ,pełnego przywrócenia suwerenności i integralności terytorialnej Ukrainy w granicach uznanych na arenie międzynarodowej”. Podstawowym narzędziem miały pozostawać sankcje gospodarcze, pomoc w dostawach materiału wojennego oraz obecność obserwatorów międzynarodowych w akwenach Morza Czarnego, Morza Azowskiego i Cieśniny Kerczeńskej. Deputowani Werchownej Rady wskazywali na konieczność obecności sił morskich państw trzecich, upatrując w nich jedyny czynnik zdolny zabezpieczyć Ukrainę przed dalszą eskalacją napięcia. Przy tej okazji zwracali uwagę na fiasko dotychczasowej polityki pacyfikacji konfliktu, która — zamiast przyczynić się do przywrócenia integralności terytorialnej Ukrainy i zakończenia okupacji Autonomicznej Republiki Krymu, miasta Sewastopol i części regionów Doniecka i Ługańska - sprowadziła na państwo ukraińskie kolejne zagrożenie ze strony agresywnego sąsiada. Całości rezolucji dopełniły ostrzeżenia przed globalnymi konsekwencjami polityki folgowania działaniom zaczepnym Federacji, jak również przed budową gazociągu Nord-Stream 2 określonej dobitnie jako ,,projekt, który nie leży w interesie Europy, a jedynie w interesie Federacji Rosyjskiej i stanowi zagrożenie dla bezpieczeństwa całego regionu krajów bałtyckich i Europy Północnej"'. Niemniej ważnym aktem politycznym było uchwalenie, zgodnie z ust. 7 art. 85 i ust. 5 art. 103 konstytucji Ukrainy ${ }^{10}$, postanowienia o przeprowadzeniu wyborów prezydenta Ukrainy. Wyznaczenie daty elekcji na dzień 31 marca 2019 r. miało służyć przede wszystkim podkreśleniu przed zagranicą stabilności funkcjonowania państwa. Był to również czytelny sygnał dla obywateli

9 Ibidem.

${ }^{10} \mathrm{~W}$ art. 85 precyzującym uprawnienia Werchownej Rady w ust. 7 zapisano, że do prerogatyw Izby należy (ust. 7) ,zarządzanie wyborów Prezydenta Ukrainy w terminie wyznaczonym w niniejszej Konstytucji”. Z kolei w art. 103, dotyczącym wyboru prezydenta Ukrainy, w ust. 5 zapisano, że ,zwykłe wybory Prezydenta Ukrainy przeprowadza się w ostatnią niedzielę października w piątym roku kadencji Prezydenta Ukrainy. W razie przedterminowego skrócenia kadencji Prezydenta Ukrainy, wybory Prezydenta Ukrainy przeprowadza się w ciągu dziewięćdziesięciu dni od dnia zakończenia kadencji” (Konstytucja Ukrainy, Warszawa 1999). W przypadku prezydentury Poroszenki, wybranego w wyborach następujących po tzw. rewolucji godności znajduje zastosowanie druga część tego przepisu. Vide A. Furier, Europa Wschodnia po 1991 roku — między Wschodem a Zachodem, [w:] Studia europejskie w Polsce, red. T. Czapiewski, M. Smolaga, Szczecin 2018, s. 187-188. 
Ukrainy, że niezależnie od ingerencji wschodniego sąsiada w wewnętrzne sprawy kraju, państwo ukraińskie zachowywało zdolność funkcjonowania.

\section{UDZIAL WERCHOWNEJ RADY W DZIALANIACH WSPIERAJACYCH ORGANY WYKONAWCZE PAŃSTWA}

Najważniejszymi czynnościami, jakich podjęli się parlamentarzyści Werchownej Rady, były działania propagandowe. Celowali w nich przede wszystkim członkowie prezydium ukraińskiego przedstawicielstwa. Nie sposób nie odnieść wrażenia, że odbiorcami wypowiedzi parlamentarnego kierownictwa, mimo że padały one z mównicy parlamentu, nie byli bynajmniej deputowani czy politycy. W zależności od politycznego zapotrzebowania adresowane były albo na użytek szerokiego odbioru ze strony społeczeństwa ukraińskiego, albo też kierowane wprost do opinii międzynarodowej. W pierwszych godzinach następujących po incydencie kerczeńskim w wypowiedziach przeznaczonych dla odbiorcy zewnętrznego przodowała wiceprzewodnicząca Werchownej Rady, Irina Heraszczenko. Oficjalnie jej tezy stanowiły głos w dyskusji na rzecz wsparcia działań prezydenta i uzyskania parlamentarnej aprobaty do wprowadzenia stanu wojennego. Zważywszy jednak, że temat ten stanowił zaledwie margines wypowiedzi, jak również że większość deputowanych pozostawała przekonana co do celowości działań zapowiadanych przez głowę państwa, zwracały uwagę inne treści, mocno zaakcentowane przez Heraszczenko. W jej przekazie dominowała jednoznaczna deklaracja, że prezydent Ukrainy ,nie zostanie wybrany przez Moskwę, lecz wyłącznie przez naród ukraiński" ${ }^{11}$. Oświadczenie to zostało dopełnione podaniem do publicznej wiadomości daty wyborów, które miały odbyć się 31 marca. Wypowiedzi wiceprzewodniczącej Werchownej Rady nie sposób odczytywać inaczej niż jako oficjalnego dementi stanowiska strony rosyjskiej, usiłującej przedstawić incydent kerczeński na forum międzynarodowym (w Radzie Bezpieczeństwa ONZ) jako akt agresji przeciwko federacji sprowokowany przez czynniki w Kijowie, dążące do odsunięcia w czasie w czasie wyborów głowy ukraińskiego państwa. Jak się również wydaje, na użytek opinii publicznej za granicą uwypuklony został młody wiek zatrzymanych marynarzy.

W przekazie zewnętrznym i wewnętrznym została wykorzystana natomiast wizyta przewodniczącego Parlamentu Europejskiego, Antonio Tayaniego. Odwiedziny polityka europejskiego stworzyły przede wszystkim kierownictwu Werchownej Rady okazję do zamanifestowania zarówno sprzeciwu wobec agresywnych dążeń Kremla, jak i podkreśleniu europejskich aspiracji Ukrainy. Incydent kerczeński spowodował, że to zagadnienie rosyjskiej napaści wysunęło się na plan pierwszy. Przewodniczący A. Parubij umiejętnie wykorzystał okazję dla uwypuklenia faktu, że agresji rosyjskiej nie wolno było traktować wyłącznie jako zagadnienia militarnego. Wskazując na Moskwę jako źródło destabilizacji sfery gospodarczej i energetycznej, podkreślił, że w swych agresywnych poczynaniach Rosjanie wykorzystywali nie tylko zasoby wojskowe, lecz również w sektorze

${ }^{11}$ Вибори Президента України — Верховного Головнокомандувача ЗСУ відбудуться 31 березня наступного року, i його обиратиме не Москва, а виключно український народ, „Hołos Ukrainy” 2018, nr 224, s. 3. 
energetycznym szczególnie w obszarze dystrybucji gazu. Dlatego szef parlamentu Ukrainy wezwał parlament europejski do przyjęcia rezolucji potępiającej budowę Nord Stream 2. Biorąc pod uwagę, że polityk ukraiński musiał mieć świadomość znikomości szans na samo poddanie tej ostatniej kwestii pod debatę w Parlamencie Europejskim (nie mówiąc już o przyjęciu tak sformułowanej rezolucji), ten fragment, podobnie jak podkreślenie postępów poczynionych przez Ukrainę na drodze integracji ze Wspólnotą, należy odczytywać jako przekaz formułowany na potrzeby komunikacji ze społeczeństwem ukraińskim. W tych samych kategoriach należy postrzegać wypowiedzi A. Tayaniego o popieraniu przez kraje członkowskie UE polityki ekonomicznego i politycznego wsparcia dla ukraińskich przemian. Ważnym elementem przekazu była informacja przewodniczącego Parlamentu Europejskiego o przyjęciu przez europosłów rezolucji dotyczącej sytuacji na Morzu Azowskim, pozwalająca najważniejszym czynnikom politycznym Ukrainy na formułowanie na użytek wewnętrzny narracji o bezwarunkowej solidarności narodów Europy okazanej Ukrainie w związku z agresją rosyjską ${ }^{12}$.

Niewątpliwie na oddziaływanie na światową opinię publiczną obliczona była inicjatywa wiceprzewodniczącej Werchownej Rady, Iriny Heraszczenko. Wystąpiła ona w bezprecedensowej roli przewodniczącej na naradzie poświęconej ochronie prawnej jeńców wojennych zatrzymanych przez FR w rejonie Cieśniny Kerczeńskiej. O tym, że zebranie miało na celu stworzenie odpowiedniej narracji, świadczył komunikat ogłoszony po zakończeniu zgromadzenia deputowanych. W niewielkim stopniu bowiem odnosił się on do możliwości udzielenia pomocy przetrzymywanym marynarzom ${ }^{13}$. Zasadniczą treść dokumentu stanowił katalog naruszeń prawa międzynarodowego przez FR. Mocno też zaakcentowano w nim sam fakt bezprawnego zatrzymania marynarzy, pozbawienia ich pomocy prawnej, psychologicznej i lekarskiej, a także opieki konsularnej oraz zatajanie przez władze wojskowe FR informacji o miejscu ich przetrzymywania. Niewątpliwie deputowani, mając świadomość znikomej efektywności presji, wykorzystali fakt uwięzienia marynarzy dla utrwalenia negatywnego wizerunku Rosji i ukazania jej jako agresora nieliczącego się z prawami człowieka oraz duchem i literą prawa międzynarodowego ${ }^{14}$.

Inną kategorią czynności podejmowanych przez prezydium Werchownej Rady były działania wspierające rząd i ministra spraw zagranicznych w kontaktach z zagranicą. Do takich posunięć należała wizyta A. Parubija w Kwaterze Głównej NATO i spotkanie z jej szefem - Jensem Stoltenbergiem. W przeciwieństwie do wizyty Tayaniego w Kijowie Parubij w Brukseli w większym stopniu starał się uzyskać konkretne deklaracje i decyzje, o czym świadczyła otwarcie wyartykułowana prośba wystosowana pod adresem społeczności międzynarodowej: „Wszyscy potrzebujemy aktywnej reakcji wolnego świata na zbrodnie Rosji. Dlatego wzywam państwa członkowskie NATO do

12 Голова Верховної Ради України Андрій Парубій передав Звернення Верховної Ради України у зв'язку з актом агресії Російської Федерації проти України Президенту Європарламенту Антоніо Таяні, „Hołos Ukrainy” 2018, nr 224, s. 3.

${ }_{13}$ Ірина Геращенко провела робочу нараду щодо юридичного захисту військовослужбовців, захоплених Російською Федерацією в районі Керченської протоки, „Hołos Ukrainy” 2018, nr 224, s. 8.

${ }_{14}$ Маємо скоординувати дії задля звільнення наших військовослужбовців, „Hołos Ukrainy” 2018, nr 227, s. 3. 
zwiększenia obecności ich statków i kontroli powietrza w rejonie Morza Czarnego"15. Celem strategicznym przewodniczącego Werchownej Rady było jednak uzyskanie deklaracji co do perspektyw członkostwa Ukrainy w strukturach NATO, co zdecydowanie podkreślał w swych oficjalnych wystąpieniach w Brukseli. Z perspektywy bieżącego konfliktu Parubij zwracał też uwagę na dwa aspekty: konieczności zwiększenia wsparcia finansowego dla cyberobrony na Ukrainie za pośrednictwem funduszy powierniczych NATO oraz kwestię porzucenia planów budowy Nord Stream 2. Jak argumentował ukraiński polityk, pierwszy problem pozostawał istotny dla Ukrainy ze względu na obawy o ataki na ukraiński system informatyczny w trakcie wyborów głowy państwa, drugi zaś wynikał z faktu, że projekt budowy drugiej nitki gazociągu był przedsięwzięciem politycznym, a nie ekonomicznym. Zdaniem Parubija, „Nord Stream 2 to sposób bezpośredniego szantażu i nierównowagi między Unią Europejską a Ukrainą, z której korzysta Putin. Dlatego North Stream 2 powinien zostać zatrzymany”. Choć wizycie w Brukseli przyświecały konkretne cele polityczne, nie oznaczało to bynajmniej, że przewodniczący Werchownej Rady nie wykorzystał okazji, aby przedstawić zachodnioeuropejskiej opinii publicznej ukraiński punkt widzenia i osiągnąć również cele wizerunkowe. Parubij był najprawdopodobniej jednym z tych polityków ukraińskich, który najbardziej obrazowo, a jednocześnie najbardziej dosadnie potrafił zestawić wizerunek Federacji kształtowany przez jej dyplomację z rzeczywistością, której obrazem była sytuacja na Ukrainie ${ }^{16}$. W wystąpieniach publicznych podkreślał, że w obecnej sytuacji jedynie Ukraina pozostawała ofiarą zbrodniczej działalności Kremla, domagał się zdecydowanej reakcji polityków świata zachodniego, a przede wszystkim wskazywał na konieczność nałożenia na Rosję sankcji ekonomicznych. Apel przewodniczącego Werchownej Rady miał spotkać się ze zrozumieniem europarlamentarzystów. Dowodem tego miała być zapowiedź kontynuacji polityki sankcji wobec FR oraz możliwość rozszerzenia katalogu restrykcji przy jednoczesnym określenia czasu ich trwania na nie mniej niż rok ${ }^{17}$. Wymiernym osiągnięciem A. Parubija miała być deklaracja o zwiększeniu finansowego wsparcia państw Sojuszu na rzecz przeciwdziałania cyberatakom inicjowanym przez Rosję. Kwestia ta miała być szczególnie istotna wobec obaw o możliwość niejawnej ingerencji Kremla w proces wyboru prezydenta Ukrainy, zwłaszcza w kontekście jednoznacznie deklarowanej determinacji deputowanych Werchownej Rady przeprowadzenia elekcji $\mathrm{w}$ terminie określonym przepisami konstytucji ${ }^{18}$. W kategoriach ograniczonego sukcesu należy postrzegać również uzyskanie przez Parubija deklaracji o konieczności poszanowania statusu wód międzynarodowych. Wprawdzie ostateczna deklaracja Parlamentu

15 Андрій Парубій закликав країни-члени НАТО збільшити присутність своїх кораблів і повітряного контролю в акваторії Чорного моря, „Hołos Ukrainy” 2018, nr 225, s. 1.

16 Jak stwierdził Parubij: ,,Jeśli w poprzednich latach Rosja ukryła zbrodnicze działania swojej armii podczas aneksji Krymu i Donbasu, stale maskując swoje wojsko, to teraz uczyniła to otwarcie, bez ukrywania, pod rosyjskimi flagami [...] Putin testuje swą siłę i czeka, aż cywilizowany świat zareaguje na jego zbrodnie". Ibidem.

17 T. Varshalomidze, Ukraine asks for NATO vessels in Sea of Azov over Russia standoff, http://www. aljazeera.com, 12 XII 2018, dostęp 20 IV 2019.

18 A. Paul, The Sea of Azov should not become a Russian lake, „European Policy Center”, 6 XII 2018. 
Europejskiego ${ }^{19}$ odbiegała od postulowanego przez przewodniczącego stwierdzenia, że „Morze Azowskie nie jest i nie może być własnością Federacji Rosyjskiej”, niemniej sam fakt potępienia działań Kremla przysparzał Ukrainie konkretny kapitał polityczny ${ }^{20}$.

Inną kategorią działań były czynności ustawodawcze obliczone na uporządkowanie statusu osób, w odniesieniu do których organy Ukrainy rościły sobie prawo do pociągnięcia do odpowiedzialności karnej za czyny zaistniałe w wyniku ,agresji zbrojnej, konfliktu zbrojnego i czasowej okupacji terytorium Ukrainy"21. Werchowna Rada wzięła na siebie ciężar stworzenia ram prawnych pozwalających Ministerstwu Spraw Wewnętrznych i Ministerstwu Sprawiedliwości na wszczęcie działań z jednej strony przeciwko osobom i instytucjom naruszającym prawa obywateli Ukrainy ${ }^{22} \mathrm{z}$ drugiej zaś - przeciwko obywatelom Ukrainy współdziałającym z agresorem na terytoriach podległych czasowej okupacji. Propozycje ustawodawcze szły również w kierunku penalizacji osób wymuszających zmianę statusu prawnego obywateli Ukrainy i w sposób bezprawny wymuszający działania niezgodne z ich wolą (np. narzucenie obywatelstwa państwa-agresora mieszkańcom terenów okupowanych). Rozpatrywaniu rozwiązań towarzyszyła świadomość - uwypuklona zresztą wcześniej, w toku dyskusji w Komisji wsparcia legislacyjnego - że projektowane rozwiązanie nie uwzględniało wymogów ustawy o jednolitym rejestrze ludności, w zakresie identyfikacji osób posiadających obywatelstwo ukraińskie lub prawo stałego pobytu na terytorium Ukrainy. Niemniej posłowie Werchownej Rady wobec pilności i konieczności legislacyjnego uregulowania kwestii ustalenia lub przywrócenia statusu prawnego osób zamieszkujących terytoria utracone w wyniku agresji zewnętrznej i czasowej okupacji terytorium Ukrainy opowiedzieli się za przyjęciem ustawy ${ }^{23}$. Niewątpliwie ważnym elementem wsparcia bezpośredniego działań rządu była też okazana przez Werchowną Radę gotowość do nowelizacji budżetu ${ }^{24}$, jeśli rząd zgłosiłby potrzebę takiego rozwiązania.

${ }^{19}$ European Parliament resolution on the situation in the Sea of Azov, Komunikaty Unions, 12 XII 2018; Очільники НАТО і Свропарламенту після зустрічей з Головою Верховної Ради України оприлюднили заяви, в яких засудили дії Кремля та закликали звільнити українських моряків і кораблі негайно, „Hołos Ukrainy” 2018, nr 225, s. 13.

${ }^{20}$ Голова Верховної Ради Андрій Парубій: Найближчими тижнями у Європарламенті розглянуть питання щодо посилення та продовження санкцій проти Російської Федерації, „Ukrinform” (28 XI 2018); Потрібна активна реакція на злочини Pociï, „Hołos Ukrainy” 2018, nr 226, s. 1-2.

${ }^{21}$ Werchowna Rady Ukrainy. Zbiór projektów ustaw, druk nr 8560: projekt ustawy o odpowiedzialności karnej za czyny zaistniałe w wyniku agresji zbrojnej, konfliktu zbrojnego i czasowej okupacji terytorium Ukrainy.

${ }^{22}$ Werchowna Rady Ukrainy. Zbiór projektów ustaw, druk nr 9298: projekt ustawy o zapewnieniu praw i wolności osób wewnętrznie przesiedlonych; Werchowna Rady Ukrainy. Zbiór projektów ustaw, druk nr 9355: projekt ustawy w sprawie rozszerzenia zakazu przeniesienia własności gruntów rolnych.

${ }^{23}$ Комітет рекомендує Верховній Раді прийняти за основу законопроект про врегулювання правового статусу осіб, стосовно яких порушено законодавство України про кримінальну відповідальність, кримінальне процесуальне, кримінально-виконавче законодавство України внаслідок збройної агресії, збройного конфлікту, тимчасової окупації території України, „Hołos Ukrainy” 2018, nr 227, s. 12.

${ }^{24}$ Werchowna Rady Ukrainy. Zbiór projektów ustaw, druk nr 9356: projekt ustawy w sprawie budżetu państwa na $2018 \mathrm{r}$. 


\section{DZIALANIA WERCHOWNEJ RADY W POCZĄTKACH „KRYZYSU AZOWSKIEGO” NIEZWIĄZANE Z „INCYDENTEM KERCZEŃSKIM”}

Choć oczywiście zagadnienia związane z utrzymaniem integralności państwa zdominowały debatę polityczną w ukraińskim przedstawicielstwie narodowym, nie oznaczało to, że parlament poświęcił się wyłącznie roztrząsaniu zagadnień związanych z agresywną postawą Federacji. Na podstawie porządku posiedzenia Werchownej Rady z 26 listopada 2018 r., można było nawet wyprowadzić mylny wniosek, że wydarzenia na Morzu Azowskim nie stanowiły zasadniczego zagadnienia w trakcie obrad. Przeczą temu jednak podstawowe informacje na temat długości i dogłębności dyskusji, jaką deputowani poświęcili temu zagadnieniu. Jakkolwiek agresja FR i utrzymujący się stan zagrożenia sprawiły, że nie było w tym dniu ważniejszego tematu, nie oznaczało to bynajmniej, że Werchowna Rada ograniczyła się wyłącznie do debaty nad wrogimi posunięciami ze strony FR. Mimo napięć w polityce międzynarodowej posłowie zdołali przedyskutować projekty kilku ustaw, które wcześniej zostały przyjęte przez odpowiednie komisje. Należały do nich m.in. projekty zmian w ustawie o odpowiedzialności za przestępstwa $\mathrm{w}$ dziedzinie rozwoju obszarów miejskich ${ }^{25}$ oraz o rynku energii elektrycznej $^{26}$. Przyjęli również — z rekomendacji Komisji Ochrony Środowiska, Wykorzystania Zasobów Naturalnych i Eliminacji Skutków Katastrofy w Czarnobylu — projekt rezolucji w sprawie przyjęcia projektu ustawy o substancjach zubożających warstwę ozonową i emisji gazów cieplarnianych ${ }^{27}$. Na wniosek tej samej Komisji przyjęto projekt ustawy o zmianach w ustawie o statusie i ochronie socjalnej obywateli dotkniętych katastrofą w Czarnobylu ${ }^{28}$. Deputowani przeprowadzili również dyskusję nad ,zmianą aktów prawnych dotyczących przewozu dzieci w pojazdach zaopatrzonych w silnik" "29, reformą sądownictwa ${ }^{30}$ oraz szkolnictwa wyższego ${ }^{31}$.

Również w kolejnych dniach kryzysu incydent kerczeński nie był jedynym wydarzeniem, któremu deputowani poświęcali całą swą uwagę. Już 27 listopada deputowani

${ }^{25}$ Werchowna Rady Ukrainy. Zbiór projektów ustaw, druk nr 7136: projekt ustawy o odpowiedzialności za przestępstwa w dziedzinie rozwoju obszarów miejskich.

${ }^{26}$ Werchowna Rady Ukrainy. Zbiór projektów ustaw, druk nr 9223: projekt ustawy o rynku energii elektrycznej.

27 Werchowna Rady Ukrainy. Zbiór projektów ustaw, druk nr 9082: projekt ustawy o substancjach zubażających warstwę ozonową i emisji gazów cieplarnianych.

28 Werchowna Rady Ukrainy. Zbiór projektów ustaw, druk nr 9152: projekt zmiany ustawy o statusie i ochronie socjalnej obywateli dotkniętych katastrofą w Czarnobylu.

${ }^{29}$ Werchowna Rady Ukrainy. Zbiór projektów ustaw, druk nr 6720: projekt rezolucji w sprawie zmiany ustawy o ruchu drogowym.

${ }^{30}$ Werchowna Rady Ukrainy. Zbiór projektów ustaw, druk nr 8533: projekt rezolucji w sprawie przyjęcia projektu ustawy o zmianach niektórych aktów ustawodawczych służących przezwyciężeniu opóźnień w orzeczeniach sądowych.

31 Werchowna Rady Ukrainy. Zbiór projektów ustaw, druk nr 9103: projekt uchwały w sprawie odrzucenia projektu ustawy o zmianach w ustawie o szkolnictwie wyższym w zakresie usprawnienia procedury wyboru i mianowania kierowników zakładów wchodzących w skład instytucji szkolnictwa wyższego i ich zastępców. 
poświęcili stosunkowo wiele czasu na debatę nad zagadnieniami związanymi z rozwojem ukraińskiego sportu, podejmując m.in. dyskusję nad rozporządzeniem ministra ds. młodzieży i sportu dotyczącym kryteriów kwalifikacji sportowców niepełnosprawnych do reprezentacji narodowej ${ }^{32}$. Przyjęcie rozporządzenia wymagało rozwiązania politycznego problemu, jakim była możliwość udziału w przygotowaniach reprezentacji osób mieszkających na stałe na Ukrainie i nieposiadających ukraińskiego obywatelstwa (zarówno cudzoziemców, jak i bezpaństwowców) ${ }^{33}$. Ten sam resort pozostawał inicjatorem uchwalenia ustawy o przystąpieniu Ukrainy do poszerzonej częściowej umowy w sprawie sportu (EPAS, Enlarged Partial Agreement on Sport), zainicjowaną w 2007 r. przez państwa członkowskie Rady Europy. Deputowani wyrazili aprobatę dla wartości przyświecających porozumieniu, uznając przede wszystkim uregulowania takich kwestii dotykających ukraiński sport jak manipulacja wynikami sportowymi (tzw. match fixing) i wykorzystywania sportu do osiągania celów politycznych, migracje w sporcie, dyskryminacja sportowców ze względu na kraj pochodzenia, ksenofobia i rasizm ${ }^{34}$. Część członków ukraińskiego parlamentu wraz z przewodniczącym Anidrijem Parubijem wzięła udział w obchodach 100-lecia powołania Ukraińskiej Akademii Nauk. W okolicznościowej debacie jubileuszowej nie zabrakło akcentów politycznych, wskazujących na rolę Akademii w reformowaniu wszystkich sfer życia publicznego. Jednak jednocześnie podkreślona została jej właściwa rola, tj. organizatora i wykonawcy badań podstawowych i stosowanych, promotora polityki państwa w dziedzinie działalności naukowej i technologicznej oraz stymulatora rozwoju społeczno-politycznego, społeczno-gospodarczego i kulturalnego ${ }^{35}$. W kontekście polityki międzynarodowej zwracało również uwagę przyjęcie projektu rezolucji w sprawie ustanowienia wspólnej komisji parlamentarno-rządowej ds. wdrażania postanowień układu o stowarzyszeniu między Ukrainą a Unią Europejską, Europejską Wspólnotą Energii Atomowej $i$ ich państwami członkowskimi ${ }^{36}$.

Innym problemem istotnym z punktu widzenia ukraińskiego państwa, nad którym pochylili się deputowani Werchownej Rady, była kwestia reformy emerytalnej. Rosyjska napaść nie wpłynęła na zmianę planów prezydium ukraińskiego parlamentu i nie

${ }^{32}$ Werchowna Rady Ukrainy. Zbiór projektów ustaw, druk nr 1444-18: projekt rozporządzenia Ministerstwa Sportu w sprawie procedur selekcji sportowców niepełnosprawnych i ich udziału w rywalizacji międzynarodowej.

33 Dziennik Urzędowy Ministerstwa ds. Młodzieży i Sportu Ukrainy, rozporządzenie nr 5443 z 27 listopada 2018 r.

${ }^{34}$ D. Bodin, G. Sempé, Ethics and Sport in Europe, Paris 2011, s. 97 i n.; J.-L. Chappelet, Autonomy of Sport in Europe, Strasbourg 2010, s. 68 i n.

35 Голова Верховної Ради України Андрій Парубій привітав Колектив Національної академії наук України та Президента Національної академії наук України академіка НАН України Патона Б.С. зі сторіччям, „Hołos Ukrainy” 2018, nr 224, s. 8.

36 Werchowna Rady Ukrainy. Zbiór projektów ustaw, druk nr 9343: projekt rezolucji w sprawie ustanowienia wspólnej komisji parlamentarno-rządowej ds. wdrożenia postanowień układu o stowarzyszeniu między Ukrainą a Unią Europejską, Europejską Wspólnotą Energii Atomowej i ich państwami członkowskimi. 
spowodowała odroczenia dyskusji nad kształtem systemu zabezpieczenia emerytalnego między pierwszym zastępcą przewodniczącego Komisji polityki społecznej, zatrudnienia i reformy emerytalnej Siergieja Kaplina a szefem państwowego funduszu emerytalnego Eugenem Kapinusem. Obaj rozmówcy wyrazili potrzebę jak najszybszego wprowadzenia $\mathrm{w}$ życie projektu ustawy umożliwiającej wdrożenie systemu finansowania obowiązkowego ubezpieczenia emerytalnego ${ }^{37}$ oraz ustawy o obowiązkowym kapitałowym zabezpieczeniu emerytalnym ${ }^{38}$.

W kontekście agresji rosyjskiej szczególnego znaczenia nabierała debata przeprowadzona w Komisji Paliw i Energii, Polityki Jądrowej i Bezpieczeństwa Jądrowego. Choć dyskusja zaplanowana została ze znacznym wyprzedzeniem i choć w debacie dominowały argumenty ekonomiczne i infrastrukturalne, to wymiana zdań na temat osiągnięcia zakładanych przez państwo celów w obszarze produkcji gazu — siłą rzeczy - musiała choćby w minimalnym stopniu uwzględniać kontekst uniezależnienia się od dostaw ze strony Rosji. Mimo że w trakcie posiedzenia kontekst rosyjski nie był nadmiernie eksploatowany i stanowił margines merytorycznej dyskusji nad osiągnięciem strategicznych celów wydobycia gazu ziemnego i poprawy zarządzania zasobami naturalnymi, to jednak trudno uznać za przypadkową opinię wyrażoną przez pierwszego zastępcę przewodniczącego Parlamentarnego Zespołu ds. Paliw i Energii, Oleksandra Dombrowskiego. Był on bowiem tym politykiem, który najostrzej stawiał sprawę znalezienia narzędzi i decyzji niezbędnych do eksploatowania własnych zasobów energetycznych Ukrainy i uzyskania niezależności i bezpieczeństwa energetycznego. Wydaje się również, że kierunek dyskusji w postaci prób wypracowania mechanizmu współinwestowania środków publicznych i prywatnych w sektor wydobywczy wynikał z ocen bieżącej sytuacji i obiektywnej oceny na temat trudności znalezienia inwestora z zagranicy w momencie braku pełnej stabilizacji. Potwierdzeniem tegoż pozostawały stwierdzenia Olega Prokhorenki, prezesa koncernu „Ukr-gaz-wydobuwanija”, wskazującego na biurokratyczne przeszkody uniemożliwiające pozyskanie odpowiedniego kapitału niezbędnego dla stworzenia podstaw infrastrukturalnych i zwiększenia rozmiarów wyzyskania zasobów krajowych ${ }^{39}$.

Jednak już w dwa dni po agresji rosyjskiej w porządku obrad Werchownej Rady trudno było znaleźć elementy wskazujące na fakt, że Ukraina stała się obiektem napaści ze strony wschodniego sąsiada. W dniu 28 listopada ukraiński parlament przyjął pakiet ustaw o charakterze socjalnym, mających na celu przełamanie niekorzystnych

${ }^{37}$ Werchowna Rady Ukrainy. Zbiór projektów ustaw, druk nr 6677: projekt ustawy w sprawie zmiany niektórych aktów prawnych Ukrainy służących wprowadzeniu systemu finansowania państwowego obowiązkowego ubezpieczenia emerytalnego; Пенсійні виклики завтрашнього дня треба вирішувати вже сьогодні, „Hołos Ukrainy” 2018, nr 225, s. 6.

${ }^{38}$ Werchowna Rady Ukrainy. Zbiór projektów ustaw, druk nr 6679: projekt ustawy pod tytułem „Rezultaty reformy emerytalnej” o obowiązkowym kapitałowym zabezpieczeniu emerytalnym, przedstawiony przez Krajową Komisję Papierów Wartościowych i Giełdy.

39 Комітет 3 питань паливно-енергетичного комплексу, ядерної політики та ядерної безпеки провів круглий стіл на тему: „Досягнення цілей газовидобутку”, „Hołos Ukrainy” 2018, nr 224, s. 12. 
tendencji demograficznych. Do najważniejszych przyjętych wówczas przepisów należały zatwierdzenie ustaw wchodzących w skład „Narodowego Programu” zapewnienia płodności kobiet i zdrowia dzieci w wieku przedszkolnym do $2030 \mathrm{r}^{40}$ oraz o przeciwdziałaniu gruźlicy na lata 2019-2021; o przeciwdziałaniu HIV/AIDS na lata 2019-2023; o przeciwdziałaniu i ochronie przed chorobami zakaźnymi na lata 2019-2023. Ramy „Narodowego Programu” nie ograniczały się do obszaru wsparcia medycznego. W pakiecie rozwiązań pojawiły się, m.in. wzorowane na polskich doświadczeniach, ustawy zakładające wsparcie rodzin z dwójką i większą liczbą dzieci, wsparcie dla małoletnich z orzeczoną niepełnosprawnością, zniesienie ograniczeń w zakresie wysokości świadczeń dla rodzin wielodzietnych, rodzin zastępczych i rodzinnych domów dziecka w zależności od całkowitego dochodu osiąganego przez poszczególnych członków rodziny ${ }^{41}$ oraz o przyznaniu samotnym matkom dodatkowych 17 dni urlopu wychowawczego ${ }^{42}$ i przeciwdziałaniu pauperyzacji osób samotnie wychowujących jedno lub więcej dzieci. Kontekstu politycznego i odwołań do relacji z Rosją nie uniknięto przy okazji dyskusji nad postulatami objęcia cyklicznymi badaniami (w tym badaniami klinicznymi) potomków osób dotkniętych katastrofą w Czarnobylu, a także potomków osób biorących udział w akcji ratunkowej i likwidacji skutków zamknięcia elektrowni, jak również osób ewakuowanych ze strefy bezpieczeństwa. Niemniej należy podkreślić, że problem ten dyskutowany był w komisjach na długo przed agresją FR, a termin debaty został zaplanowany z wyprzedzeniem i intencją deputowanych nie było wywołanie tej drażliwej kwestii w sytuacji skrajnie konfliktowej. Zgoła odmiennie należy potraktować działania jedynie pozornie służące rozwiązaniu kwestii mieszkaniowych, podejmowane przez deputowanych w ostatnim dniu listopada 2018 r. Objazd państwa przez członków Komisji Polityki Społecznej, Zatrudnienia i Emerytur z wiceprzewodniczącym S. Kaplinem i relacje — przypominające bardziej czasy Związku Radzieckiego — ze spotkań miały przede wszystkim na celu pokazanie zdolności państwa do rozwiązywania żywotnych problemów zwykłych Ukraińców i konsolidację wobec władz w obliczu agresji FR ${ }^{43}$.

Ostatnie dni listopada również upłynęły deputowanym pod znakiem intensywnych prac ustawodawczych. W dniach 28-29 listopada posłowie kontynuowali prace

${ }^{40}$ Werchowna Rady Ukrainy. Zbiór projektów ustaw, druk nr 9344: projekt rezolucji Rady Najwyższej Ukrainy w sprawie dodatkowych świadczeń dla matek Ukrainy. Vide etiam „Відомості Верховної Ради України", 2002, nr 21-22, art. 135.

${ }^{41}$ Werchowna Rady Ukrainy. Zbiór projektów ustaw, druk nr 9347: projekt zmian niektórych aktów ustawodawczych Ukrainy w sprawie ochrony praw osieroconych dzieci, dzieci pozbawionych opieki rodzicielskiej i dzieci z niepełnosprawnościami; „Відомості Верховної Ради України” 2005, nr 6, art. 147.

${ }^{42}$ Werchowna Rady Ukrainy. Zbiór projektów ustaw, druk nr 9346: projekt zmian kodeksu rodzinnego w zakresie urlopów macierzyńskich. Co istotne, prawo do dodatkowych dni wolnych miało zostać zachowane nawet w wypadku ponownego zamążpójścia, jeśli okres, w którym kobieta samotnie wychowywała dziecko (dzieci) przekroczył trzy lata.

43 Перший заступник голови Комітету з питань соціальної політики, зайнятості та пенсійного забезпечення Сергій Каплін здійснив робочу поїздку на Казенне підприємство «Шосткинський казенний завод «Зірка», „Ноłos Ukrainy” 208, nr 228, s. 9. 
nad reformą kodeksu karnego ${ }^{44}$, systemu opieki medycznej ${ }^{45}$, usprawnieniem funkcjonowania obszarów wiejskich, ${ }^{46}$ przedsiębiorczości ${ }^{47}$, polityki mieszkaniowej państwa ${ }^{48}$, importem pojazdów na teren Ukrainy ${ }^{49}$. Przedstawiciele prezydium Werchownej Rady starali się również realizować wcześniej nakreślony scenariusz kontaktów z otoczeniem zewnętrznym. Przykładem tego typu działań była wizyta Oleksandra Danczenko, przewodniczącego Komisji ds. Informacji i Komunikacji, podczas oficjalnej wizyty z okazji „ukraińskiego dnia cyfryzacji” w Parlamencie Europejskim. Wizyta ta umożliwiła zaprezentowanie postępów, jakie kraj ten poczynił w dziedzinie e-gospodarki, jak również w dostosowaniu prawa ukraińskiego w zakresie rozwiązań e-commerce, rozwoju społeczeństwa informacyjnego, technologii informacyjnych i telekomunikacji w odniesieniu do standardów uregulowań obowiązujących we Wspólnocie. Umożliwiono również przedstawicielowi ukraińskiego parlamentu spotkanie i przedyskutowanie z czołowymi politykami europejskimi, m.in. z przewodniczącym Komisji Energii i Badań Energetycznych Jerzym Buzkiem, wiceprzewodniczącym Komisji ds. Jednolitego Rynku Cyfrowego Andrusem Ansipem oraz przewodniczącym Delegacji do Komisji Parlamentarnej

${ }^{44}$ Werchowna Rady Ukrainy. Zbiór projektów ustaw, druk nr 6706: projekt uchwały w sprawie odrzucenia projektu ustawy o zmianach w kodeksie postępowania karnego w sprawie określenia listy przestępstw, w przypadku których miałby obowiązywać specjalny tryb postępowania przygotowawczego; Werchowna Rady Ukrainy. Zbiór projektów ustaw, druk nr 4760: projekt uchwały w sprawie odrzucenia projektu ustawy o zmianach w kodeksie postępowania karnego w odniesieniu do odwołania od decyzji, działań lub bezczynności organów dochodzeniowych i prokuratorskich podczas działań mających na celu wyeliminowania przejawów korupcji; Werchowna Rady Ukrainy. Zbiór projektów ustaw, druk nr 9353: projekt zmian w kodeksie postępowania karnego w obszarze niektórych przepisów umożliwiających specjalne dochodzenie przedprocesowe; Werchowna Rady Ukrainy. Zbiór projektów ustaw, druk nr 8476: projekt rezolucji w sprawie odrzucenia projektu ustawy w sprawie poprawek do art. 108 ukraińskiego kodeksu postępowania karnego w sprawie zapewnienia właściwego rejestrowania zeznań.

${ }^{45}$ Werchowna Rady Ukrainy. Zbiór projektów ustaw, druk nr 6311: projekt rezolucji w sprawie przyjęcia projektu ustawy o zmianach niektórych aktów prawnych dotyczących zapewnienia bezpiecznych warunków świadczenia opieki medycznej.

${ }^{46}$ Werchowna Rady Ukrainy. Zbiór projektów ustaw, druk nr 9162: projekt rezolucji w sprawie przyjęcia projektu ustawy w kwestii podstawowych zasad polityki rolnej państwa i polityki na rzecz rozwoju obszarów wiejskich; Werchowna Rady Ukrainy. Zbiór projektów ustaw, druk nr 9022: projekt rezolucji w sprawie przyjęcia projektu ustawy o zmianach niektórych aktów prawnych w sprawie identyfikacji i rejestracji zwierząt; Werchowna Rady Ukrainy. Zbiór projektów ustaw, druk nr 9350: projekt ustawy o zmianie niektórych aktów ustawodawczych w sprawie gwarancji ochrony socjalnej obywateli mieszkających, pracujących lub studiujących w trudno dostępnych regionach i ich aktywizacji gospodarczej.

${ }^{47}$ Werchowna Rady Ukrainy. Zbiór projektów ustaw, druk nr 9351: projekt zmian w ustawie o spółkach z ograniczoną odpowiedzialnością; Werchowna Rady Ukrainy. Zbiór projektów ustaw, druk nr 9352: projekt ustawy o zmianie przepisów przejściowych kodeksu podatkowego oraz o zmianach do kodeksu celnego Ukrainy i niektórych innych aktów prawnych dotyczących importu pojazdów na obszar celny Ukrainy.

${ }^{48}$ Werchowna Rady Ukrainy, druki parlamentarne: Stanowisko Komisji Polityki Społecznej, Zatrudnienia i Emerytur z 28 listopada w sprawie przydziału dotacji mieszkaniowych zgodnie z rozporządzeniami w sprawie procedury przyznawania dotacji mieszkaniowych i zmian w uchwałach Rady Ministrów Ukrainy z 27 kwietnia 2018, nr 329 i 17 października 2018 r., nr 841.

${ }_{49}$ Werchowna Rady Ukrainy. Zbiór projektów ustaw, druk nr 9352: projekt ustawy o zmianie przepisów w prawie podatkowym Ukrainy w odniesieniu do opodatkowania pojazdów silnikowych podatkiem akcyzowym oraz o zmianach w kodeksie celnym Ukrainy dotyczącym przepisów w sferze importu pojazdów na obszar celny Ukrainy. 
Stowarzyszenia UE-Ukraina, Dariuszem Rosatim kolejnych etapów dostosowania obszaru branży IT na Ukrainie oraz reformy prawodawstwa dostosowane do wymogów obowiązujących w Unii ${ }^{50}$.

W ciągu drugiej dekady XXI w. Werchowna Rada Ukrainy pozostawała tym europejskim przedstawicielstwem narodowym, które jako jedyne dwukrotnie zmuszone było reagować na agresję zewnętrzną. Trudno jednoznacznie wnioskować, na ile wcześniejsze doświadczenia związane z koniecznością reakcji na aneksję Krymu ${ }^{51}$ wpłynęły na zachowania deputowanych w trakcie „kryzysu azowskiego”. Niemniej wyraźnie widać, że parlamentarzyści ukraińscy kierowali się w swych działaniach realizmem, utrzymując je w ramach swych konstytucyjnych uprawnień. Można zaryzykować hipotezę, że to właśnie chłodna i jednocześnie konsekwentna postawa przedstawicielstwa narodowego przyczyniła się do zminimalizowania skutków napaści na ukraińskie jednostki w cieśninie kerczeńskiej. Z jednej strony deputowani, zgodnie ze swymi konstytucyjnymi uprawnieniami, sprawnie wyposażyli przedstawicieli władzy wykonawczej (przede wszystkim prezydenta, ale również Radę Ministrów) w instrumenty właściwe do prowadzenie polityki państwa w stanie wojny, z drugiej zaś umiejętnie włączyli się w działania służące przeciwstawieniu się narracji rosyjskiej, wskazującej na Ukraińców jako winnych destabilizacji regionu. Mało tego, członkowie prezydium Werchownej Rady wydawali się skuteczniejsi od przedstawicieli służby zagranicznej w działaniach podkreślających pro-europejskie aspiracje Ukrainy i w domaganiu się od polityków i społeczności międzynarodowej reakcji na postępowanie Rosjan. Jednocześnie Werchowna Rada utrzymała zdolność do wypełniania swego głównego zadania, tj. stanowienia prawa. Nie wydaje się, aby agresja FR zasadniczo wpłynęła na wykonywanie przez ukraiński parlament działań ustawodawczych. Mimo zewnętrznych prób destabilizacji państwa izba bez większych zawirowań przeprowadziła wcześniej zaplanowane zmiany w obszarze reform prawnych, administracyjnych, społecznych i gospodarczych, a także w ustawowym terminie uchwaliła budżet państwa. Swymi działaniami stworzyła też argumenty dla tezy o politycznej stabilności Ukrainy i braku jej podatności na wejście w orbitę wpływów rosyjskich.

\section{BIBLIOGRAFIA}

ŹRÓDŁA

Kancelaria Prezydenta Ukrainy. Dekrety Prezydenta Ukrainy.

Konstytucja Ukrainy, wstęp i tłum. Ewa Toczek, Wydawnictwo Sejmowe, Warszawa 1999.

Sekretariat Przewodniczącego Werchownej Rady Ukrainy.

Werchowna Rady Ukrainy. Zbiór projektów ustaw.

${ }^{50}$ Голова Комітету з питань інформатизації та зв'язку Олександр Данченко під час офіційного візиту до інституцій ЄС виступив на «Ukrainian digital day» у Європейському парламенті, „Ноłos Ukrainy" 2018, nr 224, s. 12.

${ }^{51}$ Vide inter aliam S.A. Sotiriou, The irreversibility of history. The case of the Ukrainian crisis (2013-2015), [w:] The Ukrainian Crisis. The Role of, and Implications for, Sub-State and Non-State Actors, red. T. German, R. Karragiannis, New York 2018, s. 53 i n. 
Wy dawnictwa c iąg łe

„Dziennik Urzędowy Ministerstwa ds. Młodzieży i Sportu Ukrainy”, 2018.

„Hołos Ukrainy” 2018.

„Washington Post” 2018.

„Widmosti Werchownej Rady Ukrainy” 1992, 2018.

PIŚMIENNICTWO

Bodin D., Sempé G., Ethics and Sport in Europe, Council of Europe Publishing, Paris 2011.

Chappelet J.-L., Autonomy of Sport in Europe, Council of Europe Publishing, Strasbourg 2010.

Furier A., Europa Wschodnia po 1991 roku - między Wschodem a Zachodem, [w:] Studia europejskie w Polsce, red. T. Czapiewski, M. Smolaga, Instytut Politologii i Europeistyki Uniwersytetu Szczecińskiego, Szczecin 2018.

Paul A., The Sea of Azov should not become a Russian lake, „European Policy Center”, 6 XII 2018.

Sotiriou S.A., The irreversibility of history. The case of the Ukrainian crisis (2013-2015) [w:] The Ukrainian Crisis. The Role of, and Implications for, Sub-State and Non-State Actors, red. T. German, R. Karragiannis, Routledge, New York 2018, https://doi.org/10.4324/ 9781315186719-4.

Varshalomidze T., Ukraine asks for NATO vessels in Sea of Azov over Russia standoff, http://www. aljazeera.com, 12 XII 2018. 